\title{
CONTRIBUTIONS TO THE EVALUATION OF PHYSICAL TRAINING FOR STUDENTS SPECIALISED IN ALPINE SKIING
}

\author{
Wilhelm Robert GROSZ ${ }^{1}$
}

\begin{abstract}
The research approach consisted in the implementation of new tests in the physical training evaluation of the students from the Faculty of Physical Education and Mountain Sports from Brașov, in the third year of Bachelor in alpine skiing. The subjects of the research were ten students of FEFSM Brașov. The research activity took place during the 14 weeks of the first semester of the academic year 2018-2019. The objective was to participate and achieve good performances at the National University Ski \& Snowboard Championship in 2019, slalom and giant slalom events. The initial testing was performed on October 5, 2018, and the final one on January 18, 2019. In the period between the tests, sports training programs were implemented that aimed primarily at developing speed motor quality in all its forms and coordination skills. The research results highlight both the progress of all subjects and the very good results obtained in the targeted ski events, national university champion titles and rankings among the top six places.
\end{abstract}

Key words: alpine skiing, physical test, evaluation, students.

\section{Introduction}

This research approach aimed at introducing three new tests (two speed tests and an adapted Bass balance test) to assess the physical training of students of the Faculty of Physical Education and Mountain Sports in Brasov, in the third year of Bachelor in alpine skiing.

Alpine ski racing shows the technical nature of this sport, which requires both skill and motor control from the athletes
[10]. In addition to technique, alpine skiing requires all the physical abilities of an athlete, including strength (maximum strength, strength endurance and stability), power, aerobic and anaerobic capacity, balance, coordination and motor control and mobility [8], [4], [2]. The importance of developing coordinative skills in the sports training of alpine skiers with a focus on technical tests is also mentioned as the main objective [9].

\footnotetext{
${ }^{1}$ Department of Physical Education and Special Motricity, Transilvania University of Braşov
} 
Sports' training has been shown to have a positive influence on body balance regardless the type of practiced sport [11]. In the opinion of a significant number of authors, a high level of balancing ability allows to obtain many benefits related to the improvement of sports performance [11], faster rehabilitation [12] and injury prevention [3], [6], [7]. All these considerations lead to the idea that specific balance training plays an essential role as it is stated in literature [10], [5].

\section{Research Purpose}

The aim was to identify new tests that can be used to develop a procedure for objectively assessing the fitness of alpine skiers involved in top domestic competitions and to update the methodological guidance in high performance training of students involved in alpine skiing.

\section{Objectives}

The proposed objectives were:

- the implementation of an objective evaluation methodology based on scientific research;

- adapting training programs to improve coordination and balance performance.

\section{Hypothesis}

We consider that, by implementing new tests in the direction of assessing the physical training of students participating in internal competitions, their results in these competitions will be significantly improved.

\section{Material and Methods}

Experimental approach to the problem
The study was designed to assess the implementation of new ways to test the level of development of skiers' coordination skills. All subjects were tested before and after a period of 14 weeks.

\section{Subjects}

The research was carried out on 10 male subjects - students in the third year, alpine skiing specialization of the Faculty of Physical Education and Mountain Sports, aged between 20 and 21 years.

\section{The content of the research}

The research was conducted in the academic year 2018-2019. The experimental method based on the pretest $=\mathrm{TI}$ and post-test $=\mathrm{TF}$ model was chosen [1] to obtain a clear picture of the efficiency of the introduction of the three proposed tests.

The initial testing (TI) was performed on 05.10.2018. After that, during 14 weeks, sports training programs were implemented. They aimed primarily at developing the speed in all its forms of manifestation and the coordination skills, all these standing for the applied intervention which was made to assure a high level of coordination (dynamic balance, core stability), strength and speed.

The final testing (TF) was performed on 18.01.2019.

\section{Test procedures:}

1. Running test among the multi-coloured training cones, three-colour and fourcolour themes:

Objectives of the test: verification of coordination, memory and reaction capacity. 
Test description: The cones are placed as in figure 1. There are 5 lines with different coloured cones at $1 \mathrm{~m}$ distance from each other. The finishing line is placed $50 \mathrm{~m}$ from the start line. Two trials were allowed both for the 3-colour test and for the 4-colour test (total bypass 5 cones). Prior to execution, the subject received a note listing the colours of the cones to be bypassed (example for 3- colour task: green, blue, red, red and for four-colour task: yellow, blue, blue, red, yellow). The other subjects were not allowed to watch the execution of the tested subject as they received the same tasks when it was their turn.

Test results: the time was measured.

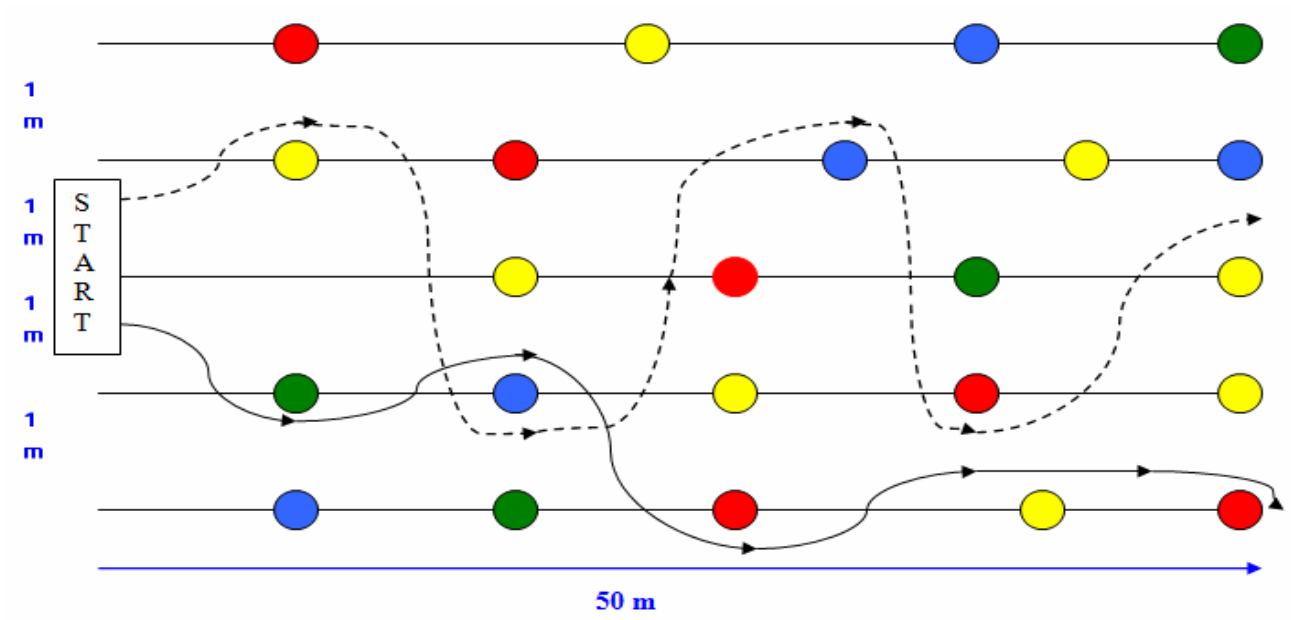

Fig. 1. Test 1 and 2 with training cones (Test 1- 3 colours THEME: green, blue, red, red; Test 2- 4 colours THEME: yellow, blue, blue, red, yellow)

Table 1

The norms for the running test among the multi-coloured training cones

\begin{tabular}{|c|c|c|c|c|c|c|c|c|}
\hline Norms & 30 pct & 40 pct & 50 pct & 60 pct & 70 pct & 80 pct & 90 pct & 100 pct \\
\hline $\begin{array}{c}\text { 3-colour } \\
\text { theme test }\end{array}$ & 11,4 & 11,2 & 11 & 10,8 & 10,6 & 10,4 & 10,2 & 10 \\
$\begin{array}{c}\text { 4-colour } \\
\text { theme test }\end{array}$ & $\mathbf{1 2 , 2}$ & $\mathbf{1 2}$ & $\mathbf{1 1 , 8}$ & $\mathbf{1 1 , 6}$ & $\mathbf{1 1 , 4}$ & $\mathbf{1 1 , 2}$ & $\mathbf{1 1}$ & $\mathbf{1 0 , 8}$ \\
\hline
\end{tabular}

2.Adapted BASS test of dynamic balance Test objectives: checking balance, coordinating body segments, correct distribution of CGM.

Test description: Only one trial was performed. The adapted Bass test of dynamic balance requirement consisted of side jumps on one lower limb and landing on the entire surface of the foot (sole), maintaining balance for five seconds in this static position, on the eleven marks of the route. There were awarded 5 points for each landing covering the mark and 
one point for each second of maintaining the balance on the mark. [1].

The statistical analysis was performed using SPSS 26.0. The normality of the distribution of data was assessed through the Shapiro-Wilk test. Student's paired t- test was used to test the significance between pre- and post-programmes to assess whether the intervention produced any modifications. The level of statistical significance was $p<0.05$.

\section{Results}

TI and TF results in the three tests

Table 2

\begin{tabular}{|c|c|c|c|c|c|c|c|c|c|c|}
\hline $\begin{array}{c}\text { TESTS } \\
1,2 \text { and } 3\end{array}$ & \multicolumn{2}{|c|}{$\begin{array}{c}\text { TI } \\
\text { 3-culour T }\end{array}$} & \multicolumn{2}{|c|}{$\begin{array}{c}\text { TI } \\
\text { 4-colour T }\end{array}$} & \multicolumn{2}{|c|}{$\begin{array}{c}\text { TF } \\
\text { 3-colour T }\end{array}$} & \multicolumn{2}{|c|}{$\begin{array}{c}\text { TF } \\
\text { 4-colour T }\end{array}$} & \multicolumn{2}{|c|}{ BASS TEST } \\
\hline Subjects/MU & $\mathrm{sec}$ & pct & $\mathrm{sec}$ & pct & $\mathrm{sec}$ & pct & $\mathrm{sec}$ & pct & TI pct & TF pct \\
\hline Subject 1 & 11,2 & 40 & 11,9 & 45 & 10,8 & 60 & 11,6 & 60 & 78 & 84 \\
\hline Subject 2 & 11,3 & 35 & 11,9 & 45 & 11 & 50 & 11,7 & 55 & 83 & 85 \\
\hline Subject 3 & 10,8 & 60 & 11,7 & 55 & 10,7 & 65 & 11,3 & 75 & 86 & 91 \\
\hline Subject 4 & 10,5 & 75 & 11,4 & 70 & 10,4 & 80 & 11,2 & 80 & 87 & 83 \\
\hline Subject 5 & 11,4 & 30 & 11,8 & 50 & 10,6 & 70 & 11,7 & 55 & 85 & 86 \\
\hline Subject 6 & 11,1 & 45 & 11,6 & 60 & 10,7 & 65 & 11,4 & 70 & 89 & 97 \\
\hline Subject 7 & 10,7 & 65 & 11,5 & 65 & 10,4 & 80 & 11,7 & 55 & 93 & 98 \\
\hline Subject 8 & 10,9 & 55 & 11,6 & 60 & 10,6 & 70 & 11,5 & 65 & 76 & 84 \\
\hline Subject 9 & 10,8 & 60 & 11,3 & 65 & 10,5 & 75 & 11,4 & 70 & 80 & 91 \\
\hline Subject 10 & 10,5 & 75 & 11,1 & 85 & 10,1 & 95 & 11 & 90 & 94 & 99 \\
\hline
\end{tabular}

\section{Research Data Interpretation}

Descriptive statistics for the three tests

Paired Samples Statistics

\begin{tabular}{|c|c|c|c|c|c|}
\hline \multicolumn{6}{|c|}{ Paired Samples Statistics } \\
\hline & & Mean & $\mathrm{N}$ & Std. Deviation & $\begin{array}{l}\text { Std. Error } \\
\text { Mean }\end{array}$ \\
\hline \multirow[t]{2}{*}{ Pair 1} & $\begin{array}{l}\text { Test initial Copete } 3 \\
\text { Colours }\end{array}$ & 54.0000 & 10 & 15.95131 & 5.04425 \\
\hline & $\begin{array}{l}\text { Test final Copete } 3 \\
\text { Colours }\end{array}$ & 71.0000 & 10 & 12.42757 & 3.92994 \\
\hline \multirow[t]{2}{*}{ Pair 2} & $\begin{array}{l}\text { Test initial Copete } 4 \\
\text { Colours }\end{array}$ & 60.0000 & 10 & 12.24745 & 3.87298 \\
\hline & $\begin{array}{l}\text { Test final Copete } 4 \\
\text { Colours }\end{array}$ & 67.5000 & 10 & 11.84389 & 3.74537 \\
\hline \multirow[t]{2}{*}{ Pair 3} & Test Initial Bass & 85.1000 & 10 & 6.00833 & 1.90000 \\
\hline & Test final Bass & 89.8000 & 10 & 6.30344 & 1.99332 \\
\hline
\end{tabular}

Table 3 
Correlation coefficient for the three tests

Table 4

Paired Samples Correlations

\begin{tabular}{|c|c|c|c|c|}
\hline & & $\mathrm{N}$ & Correlation & Sig. \\
\hline Pair 1 & $\begin{array}{l}\text { Test initial Copete } 3 \\
\text { Colours \& Test final } \\
\text { Copete } 3 \text { Colours }\end{array}$ & 10 & .790 & .007 \\
\hline Pair 2 & $\begin{array}{l}\text { Test initial Copete } 4 \\
\text { Colours \& Test final } \\
\text { Copete } 4 \text { Colours }\end{array}$ & 10 & .785 & .007 \\
\hline Pair 3 & $\begin{array}{l}\text { Test Initial Bass \& Test } \\
\text { final Bass }\end{array}$ & 10 & .766 & .010 \\
\hline
\end{tabular}

Student's t-test results for the three tests

Table 5

\begin{tabular}{|c|c|c|c|c|c|c|c|c|c|}
\hline \multicolumn{10}{|c|}{ Paired Samples Test } \\
\hline & & \multicolumn{5}{|c|}{ Paired Differences } & \multirow[b]{3}{*}{$t$} & \multirow[b]{3}{*}{ df } & \multirow[b]{3}{*}{ Sig. (2-tailed) } \\
\hline & & \multirow[b]{2}{*}{ Mean } & \multirow[b]{2}{*}{ Std. Deviation } & \multirow{2}{*}{$\begin{array}{c}\text { Std. Error } \\
\text { Mean }\end{array}$} & \multicolumn{2}{|c|}{$\begin{array}{l}\text { 95\% Confidence Interval of the } \\
\text { Difference }\end{array}$} & & & \\
\hline & & & & & Lower & Upper & & & \\
\hline Pair 1 & $\begin{array}{l}\text { Testinitial Copete } 3 \\
\text { Colours - Test final } \\
\text { Copete } 3 \text { Colours }\end{array}$ & -17.00000 & 9.77525 & 3.09121 & .23 .99279 & -10.00721 & .5 .499 & 9 & .000 \\
\hline Pair 2 & $\begin{array}{l}\text { Test initial Copete } 4 \\
\text { Colours - Testfinal } \\
\text { Copete } 4 \text { Colours }\end{array}$ & -7.50000 & 7.90569 & 2.50000 & -13.15539 & -1.84461 & -3.000 & 9 & .015 \\
\hline Pair 3 & $\begin{array}{l}\text { Testlnitial Bass - Test } \\
\text { final Bass }\end{array}$ & -4.70000 & 4.21769 & 1.33375 & -7.71715 & -1.68285 & -3.524 & 9 & .006 \\
\hline
\end{tabular}

The dependent sample or paired t-test showed that there are statistically significant differences in the final test TF compared to the initial test $\mathrm{TI}$ in each of the three proposed and applied tests: Test 1 - threecolour theme running test, Test 2 - fourcolour theme running test and Test 3 adapted Bass test of dynamic balance.

\section{Conclusions}

1. The research findings showed that the intervention on the 10 subjects materialized in the form of programmes for 14 weeks after the collection of the initial data on 05.10.2018 had effects on the group of students at the final test on
18.01.2019, the averages per pairs of tests increased significantly in the final tests.

2. For Test 1 - three-colour theme running test, $t(9)=5,499 p=0.00<0.05$.

3. For Test $2-$ four-colour theme running test, $\mathrm{t}(9)=3 \mathrm{p}=0.015<0.05$.

4. For Test 3 - adapted Bass test of dynamic balance, $t(9)=3,524 p=0.006<0.05$.

5. Considering the comparative analysis of the scores of the three tests aplied on the students group and their statistical significance, it can be consider that the implemented sports training programmes aiming primarily the developing speed motor quality in all its forms and coordination skills improved outcomes in final tests. 
6. These findings, in their turn, determined the progress of all subjects from the studied group as well as very good results in the targeted competitions, national university champion titles and top 6 places in 2019, which confirms the research hypothesis.

7. The applied programmes on the students group were a success due to the obtained results and the way the subjects reacted to this research procedure.

\section{References}

1. Epuran, M.: Metodologia cercetării activităților corporale (Research Methodology of Body Activity). Bucureşti, Edit. FEST, 2005.

2. Gilgien, M., Reid, R., Raschner, C., Supej, M. and Holmberg H-C.: The Training of Olympic Alpine Ski Racers. Front. Physiol. 9:1772. (2018) doi: 10.3389/fphys.2018.01772

3. Hrysomallis, C.: Balance ability and athletic performance Sports Medicine, vol. 41, no. 3, pp. 221-232, 2011.

4. Hydren, J.R., Volek, J.S., Maresh, C. M., Comstock, B.A., Kraemer, W.J.: Review of Strength and Conditioning for Alpine Ski Racing. In: Strength and Conditioning Journal: February 2013 Volume 35 - Issue 1, p 10-28. doi: 10.1519/SSC.0b013e31828238be

5. Jastrzębska, A.D.: Gender Differences in Postural Stability among 13-Year-Old Alpine Skiers.In: Int. J. Environ. Res. Public Health 2020, 17, 3859. https://doi.org/10.3390/ijerph1711385 9

6. Kümmel, J., Kramer, A., Giboin, L.-S., and Gruber, M.: Specificity of Balance Training in Healthy Individuals: A Systematic Review and Meta-Analysis.
In: Sports Medicine, 2016, vol. 46, no. 9, p. 1261-1271.

7. Lesinski, M., Hortobágyi, T., Muehlbauer, T., Gollhofer, A., and Granacher, U.: Effects of balance training on balance performance in healthy older adults: a systematic review and meta-analysis. In: Sports Medicine, 2015, vol. 45, no. 12, p. 1721-1738.

8. Neumayr, G., Hoertnagl, H., Pfister, R., Koller, A., Eibl, G., Raas, E.: Physical and physiological factors associated with success in professional alpine skiing. In: Int. J. Sports Med. 24, 571575. (2003). doi: 10.1055/s-200343270

9. Pelin, F., Păcurar, I.: Contributions to the evaluation methods of physical trening for the junior Alpine Skiing national team. In: Procedia-Social and Behavioral Sciences 2014, 117, p. 238-242.

10. Raschner, C., Hildebrandt, C., Mohr, J., and Müller, L.: Sex differences in balance among alpine ski racers: cross-sectional age comparisons. In: Percept. Mot. Skills 124, 1134-1150. (2017). doi: $10.1177 /$ 0031512517730730

11. Słomka, K.J., Pawłowski, M., Michalska, J., Kamieniarz, A., Brachman, A., Juras, G.: Effects of 8Week Complex Balance Training in Young Alpine Skiers: A Pilot Study. In: Biomed Res Int. 2018;2018:6804534. Published $2018 \quad$ Nov 21. doi:10.1155/2018/6804534

12. Zech, A., Hübscher, M., Vogt, L., Banzer, W., Hänsel, F., and Pfeifer, K.: Balance training for neuromuscular control and performance enhancement: a systematic review. In: Journal of Athletic Training, vol. 45, no. 4, pp. 392-403, 2010. 